$\xi=-1$

\title{
Capital Investment and Profitability Across Malaysian Construction Sectors
}

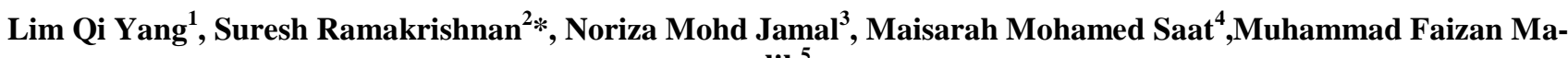 \\ lik $^{5}$ \\ ${ }^{I}$ Raffles University Iskandar, Malaysia \\ ${ }^{2,3,4,5,6}$ Faculty of Management, Universiti Teknologi Malaysia, Malaysia \\ *Corresponding authorE-mail: suresh@utm.my
}

\begin{abstract}
Capital investment and profitability are the most important factors in every firms. Capital investment will determine profitability of the firm by having efficient and effective investment portfolio to the firm. This study investigates the relationship of capital investment and profitability among Malaysia listed construction firms from 2001-2014. Furthermore, this study also analyzes the impact of capital investment on profitability in different economic sub-periods. In addition, this study also used Pooled OLS analysis and fixed effect analysis to analyze and determine the relationship between dependent and independent variables. I.e.: capital investment such as investment to asset, capital expenditure and current capital expenditure along with profitability such as return on asset and return on equity as well as the control variables namely firm size and leverage. The overall results revealed that capital expenditure have significant relationship with return on asset and return on equity. On the other hand, the relationship between capital investment and profitability are differ across different economic sub-periods will produce different outcome. Investment to asset had significant impact towards return on asset and return on equity during pre-crisis period and post-crisis period but during Global Financial Crisis period current capital expenditure has the largest impact towards profitability of the firm.
\end{abstract}

Keywords: Capital Investment,: Profitability; Construction Sector;Financial Crisis; Economic Sub-period

\section{Introduction}

In the recent decades, capital investment and profitability have been one of the major interesting research subjects due to most of the firms aiming to enter the global market and expand their business to different areas of the countries. Researchers have investigated the effect of profitability and capital investment $[1,2,3]$. Profitability is the key for firms to determine whether they can have competitive advantage over their competitors. It will reflect the performance of firms in the market. Capital investment refers to the acquisition of asset in the organization and generates earnings for the firms. For instance, plant and equipment, bond or machinery [4]. Thus, capital investment and profitability have different relationship in different circumstances and differ across different economic sub-period.

Capital investment decision is important to firms because it will affect the profitability of firms. With limited resources available in the organization, managers of firms need to forecast the market trend and allocate the resources correctly according to the portlio. Good capital investment decision will increase the profitability of a firm [5]. The existing studies focused on the developed countries and different sector across the market.

Previous studies have primarily concentrated on developed countries, to investigate the relationship between capital investment and profitability $[6,7,8]$. After a period of focussing on developed countries, the researchers changed their research trend to investigate the relationship between capital investment and profitability in developing countries. Researchers found that there was a differ- ent trend and business environment between different countries of different status $[9,10,11]$. There are limited studies that can be found in the market that are related to Malaysia context because Malaysia is still considered to be under developing or emerging countries. According to the literature review, most of the studies discuss how capital investment affects the profitability by portfolio basis. Other research in the past focusses mostly on manufacturing firms for Malaysia context because it covered most portion of Malaysia GDP[10,11].

\section{Literature Review}

Capital investment define as the manager of the organization in managing the available resources mainly money or funds in the organization to maximize the firm competitiveness and maximize the shareholder wealth. On the other hand, profitability indicates returns gain from the investment of firm's portfolio.

In the literature, profitability of the firms is mainly proxied through return on asset (ROA) and return on equity (ROE) [12, 13] The return on asset (ROA) shows how profitable is the organization according to the total asset or in another word how much return generate from the investment of the asset the organization had invested[14]. While return on equity (ROE) indicates the amount of profit generates from the shareholder equity in the organization.

Following that, Bentum [14] indicates that the financial firm performance is positively affected by $R \& D$ investment. $R \& D$ investment return normally do not originate to the investor, but the benefit will spill over to a wide variety of economy agents [15]. 
Other than this, Zhu et al [13] also observed the relationship between R\&D investment on firm's financial performance. This study concludes that firm with intensive investment in R\&D activity will have significantly larger financial performance. Moreover Burja [4] investigated the factors affecting the profitability by using return on asset as the proxy for profitability. The empirical result stated that return on asset of the firms have strong dependent relationship with the capital investment management of the firms. In addition, Heshmati and Loof [16] further conjectured a significant positive relationship between firm investment and performance behaviour of the firm.

The investigation of the relationship between financial leverage ratio and $\mathrm{ROE}$ and concluded that $\mathrm{ROE}$ and debt to total assets are positive in construction sector. It was observed profitability of firm by using ROE as the proxy and concluded that ROE has significant positive relationship with capital investment. Apart from this, Berger and Bouwman [17] also reported the significant effect of pre-crisis bank capital on the profitability of the bank around banking and market crises by using ROE as proxy.

\subsection{Problem Statement}

Recent developments in the construction sector have led to a renewed interest in conducting different research about this sector. Recent evidence suggests that there is a strong correlation between construction sectors and the economic growth in Malaysia $[16,17,18]$. Following that, construction sectors in Malaysia grew steadily during year 2009 which is the year after the 2008 global financial crisis, this observation has given researchers a new area which they can work on to investigate the impact of financial crisis on the construction sector [19]. As far as researchers are aware of, there is no study being done on construction sector in Malaysia yet. Therefore, this study discussed on how the capital investment and profitability of construction sector in Malaysia affect each other. This study also focused on how the capital investment and profitability react in prior to the 2008 global financial crisis as well as after the crisis. In the past, mostly studies were conducted to investigate the impacts of financial crisis on the profitability in different firms and sectors. However, this research is designed to investigate based on different sub-economic period - before, during and after the crisis, to determine the performance of the firms of the research sample[20,21,22].

\subsection{Objectives of the Study}

The objectives of this research are as followed:

1.To investigate the relationship between capital investment and profitability of Malaysia listed firms across construction sector.

2.To study the relationship between capital investment and profitability of Malaysia listed firms across construction sector in different sub-economic periods.

\subsection{Significance of the Study}

The significant contribution of this study can be addressing into two important issues, i.e. the body of knowledge and policy implication. Most of the previous literature focus on developed and developing countries, this study examines the relationship between capital investment and profitability based on the listed firms in the construction sector of Malaysia. Thus, this study will use two economic periods in doing analysis which are before and after the 2008 global financial crisis. From the policy implication perspective, this study is obvious as the resulting outcomes can be capitalized as guidelines to construction sector firms on the current market trend and take it as references in their business decision making process. Moreover, this study also brings benefit for the investor in construction sector of Malaysia to know more about how capital investment and profitability in construction sector is reacting in normal period and in financial crisis period which is before the financial crisis, during the financial crisis and after the financial crisis.

\subsection{Conceptual Framework}

Figure 1 shows the theoretical framework of this research. The independent variables are investment to asset, capital expenditure and current capital expenditure. These independent variables will affect the dependent variable which are return on asset (ROA) and return on equity (ROE). Other than that, control variables also being used in this research which are size and leverage. Moreover, this research will discuss about the different economic sub-period in related to financial crisis in 2008. To investigate on whether the probability was affected by different economic sub-period.



Fig. 1: Theoretical Framework on Independent, Dependent and Control Variables

\section{Methodology}

This study is a quantitative research which using all the numeric data to conduct the analysis. Quantitative study can give better understanding of the cause and effect result of the research $[23,24]$. All the variables will be tested based on different proposed hypothesis. This study utilizes secondary data that are collected from the annual reports of 37 listed firms of construction sector for the year 2001-2014 in Bursa Malaysia. The research period 2001-2014 will be divide into two periods which are before and after the financial crisis i.e. from 2001-2008 and 2009-2014. The purpose of doing this is to investigate two trends of profitability in related to before and after financial crisis in 2008.

\subsection{Variables of the Study}

The dependent variables in this research are return on asset (ROA) and return on equity (ROE). These variables will be measured by profitability ratio which is commonly used in finance and accounting field. While, the independent variable in this research is capital investment. The proxies for the measurement of capital investment are investment to asset (ITA), capital expenditure (CAPEX) and current capital expenditure (CCAPEX). Furthermore, the control variables of this research are firm size and leverage. These two variables will remain constant in the process of analyzing the outcome with the data obtained from industry.

\subsection{Hypotheses}

The proposed hypotheses for the current study are listed as below: $\mathrm{H} 1$ : There is negative relationship between the investment to asset and return on asset.

$\mathrm{H} 2$ : There is positive relationship between the capital expenditure and return on asset.

H3: There is positive relationship between the current capital expenditure and return on asset.

$\mathrm{H} 4$ : There is negative relationship between the investment to asset and return on equity. 
H5: There is positive relationship between the capital expenditure and return on equity.

H6: There is positive relationship between the current capital expenditure and return on equity.

\subsection{Pooled Ordinary Least Squares (OLS) Analysis}

Pooled Ordinary Least Squares (OLS) analysis is the core econometric analysis which important to calculate and estimate the regression line without running regression for the sample data. Pooled data can analyze the big sample data without any restriction unlike time series and cross-sectional analysis [25]. The following equation will show the formulae for the estimation of the relationship between firm profitability and capital investment: $R O A_{i t}=\alpha+\beta_{1} I T A_{i t}+\beta_{2}$ CAPEX $_{i t}+\beta_{3}$ CCAPEX $_{i t}+\beta_{4} S_{\text {SIZE }}+\beta_{5} L V R_{i t}+\varepsilon_{i t}$ The terms that can be found in the equation is stated as follow, return on asset (ROAit) and profitability ratio indicator for firm i in year $t$, investment to asset (ITA), capital expenditure (CAPEX), current capital expenditure (CCAPEX), firm size (SIZE), leverage

(LVR) and serially uncorrelated with zero mean $\left(\varepsilon_{i t}\right)$.

\subsection{Fixed Effect Analysis}

Pooled OLS analysis excludes the time invariant component from the analysis. Therefore, the current study employed the fixed effect analysis to analyze the impact of variables over time [26]. However, to determine which model is suitable between fixed and random effect, Hausman test will be conducted. Hausman test was designed to differentiate between fixed effect and random effects model in the sample data .For instances, fixed effect data is less consistent and random effect data is more efficient under null hypothesis. The equation is as below:

$R O A_{i t}=\alpha+\beta_{1} I A_{i t}+\beta_{2} C E_{i t}+\beta_{3} C C E_{i t}+\beta_{4} S I Z E_{i t}+\beta_{5} L V R_{i t}+\mu_{i}+\varepsilon_{i t}$

\section{Data Analysis and Results}

\subsection{Correlation Matrix Analysis and Trend Analysis}

Table 1: Correlation Matrix Analysis

\begin{tabular}{|c|c|c|c|c|c|c|c|}
\hline & ROA & ROE & ITA & CAPEX & CCAPEX & SIZE & LVR \\
\hline ROA & 1.0000 & $0.3339^{*}$ & -0.0364 & -0.0455 & -0.0222 & $0.0643^{* *}$ & $-0.3527^{* *}$ \\
\hline ROE & & 1.0000 & 0.0235 & 0.0180 & $-0.7390^{* *}$ & -0.0192 & 0.0410 \\
\hline ITA & & & 1.0000 & $0.0507^{*}$ & $0.0983^{*}$ & 0.0223 & 0.0463 \\
\hline CAPEX & & & & 1.0000 & $0.1137^{*}$ & -0.0146 & 0.0471 \\
\hline CCAPEX & & & & & 1.0000 & $0.0596^{* *}$ & -0.0358 \\
\hline SIZE & & & & & & 1.0000 & 0.0414 \\
\hline LVR & & & & & & & 1.0000 \\
\hline
\end{tabular}

Significance level $5 \%$ was expressed at ${ }^{*}$. The sample comprises of 518 firm-year observations from 2001 to 2014. Dependent variables are return on asset ( $\mathrm{ROA})$ and return on equity $(\mathrm{ROE})$. Independent variables are investment to asset (ITA), capital expenditure (CAPEX) and current capital expenditure (CCAPEX). Control variables are size (SIZE) and Leverage (LVR). Refer to Tables 3.1,3.2 and 3.3 for all variables definitions.

Table 1 presented a correlation matrix based on 37 firms of construction sector in Malaysia. The results show that return on asset is positively and significantly correlated to return on equity, capital expenditure at $5 \%$ level of significant. Investment to asset also has the same as return to asset which positively and significantly correlated to capital expenditure and current capital expenditure at $5 \%$ level of significant. However, return on equity is negatively correlated to current capital expenditure and firm size at 5\% level of significant.

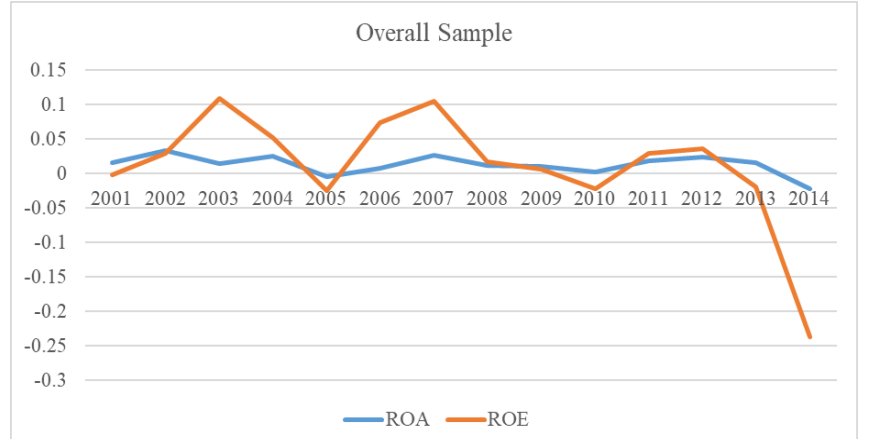

Fig. 2: Trend of construction sector firm's profitability

Figure 2 shows the trend of construction sector firms profitability from 2001 to 2014. The trend shows that return on equity always have higher trend when it rises compare to return on asset. Both figures dropped tremendously in 2014 until negative values obtained. The huge drop in return on asset and return on equity was due to the large investment of housing projects to the market. According to the productivity report $2014 / 2015$, construction sector contributed to country gross domestic product surged by $11.6 \%$. Moreover, there also significantly drop from 2008 to 2010. This is due to the global financial crisis 2008. From Figure 2, it shows that return on asset of 37 construction firms has less volatile which ranging from -0.02 to 0.03 .

\subsection{Pooled Ordinary Least Squares (OLS) Analysis Based on Overall Sample}

Pooled ordinary least square regression was applied to the study to analyses the relationship between the dependent variables (ROA $\&$ ROE) and independent variables (IA, CE, CCE).

Based on the result shown in Table 2, capital expenditure was significantly positive related to return on asset and return on equity at a significant level of $1 \%$, this result was in line with the proposed hypotheses about capital expenditure. Thus, these confirms hypotheses $\mathrm{H} 2$ and $\mathrm{H} 5$. Furthermore, investment to asset was negatively related to return on asset at significance level of $1 \%$. This do not reject hypotheses H1. However, investment to asset was found to have positive relationship with return on equity which contradict to the proposed hypotheses. Thus, hypotheses $\mathrm{H} 4 \mathrm{re}$ jected.

On the other hand, current capital expenditure had a negative relationship to return on asset and return on equity. This result is different from the proposed hypotheses. Hence, hypotheses $\mathrm{H} 3$ and H6 rejected. Besides that, the results also proposed that total debt was the important variables compare to firm size in this study. Other than that, since both F-stat value is larger than 4, this explain that the overall model is good to use as analysis in this study.

Table 2: Pooled OLS Regression among construction sector firms

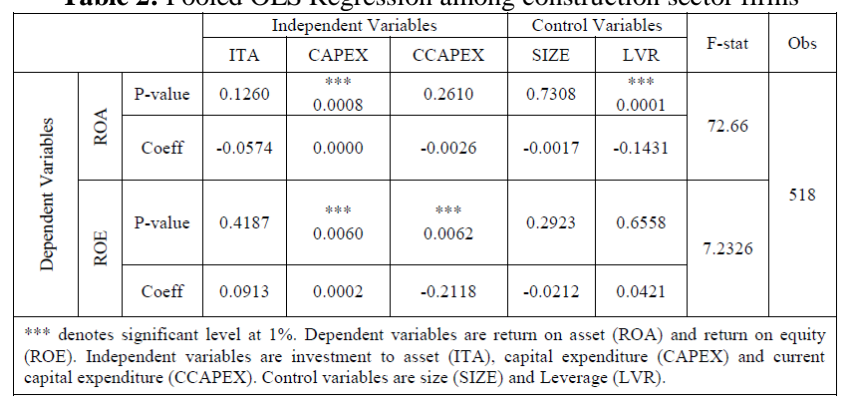

\subsection{Fixed Effect Analysis Based on Overall Sample}

Pooled ordinary least square analysis is used to analyze the relationship between capital investment and profitability. Nevertheless, it excludes time invariant component and cross sectional 
effect during the analysis. Therefore, the result obtained from fixed effect analysis will be different from Pooled ordinary least square analysis.

The result of the fixed effect analysis between dependent variables and independent variables are presented in Table 3. Investment to asset remain negatively related to return on asset but it become significant in this analysis. However, investment to asset remain positive related to return on equity at $1 \%$ of significance level. Thus, this confirms $\mathrm{H} 1$ and reject H4. Furthermore, the same result applied to capital expenditure which significant positive associated with return on asset and return on equity at a significance level of $1 \%$. Hence, failed to reject $\mathrm{H} 2$ and $\mathrm{H} 5$.

In addition, the result indicates that current capital expenditure was negatively associated to return on asset and return on equity at a significance level of $1 \%$. This result was significant to return on equity. Hence, hypotheses $\mathrm{H} 3$ and $\mathrm{H} 6$ were rejected. There are contradict result shown in the table where firm size and total debt were important to return on asset in this analysis. Besides that, this also a suitable model to be done in this study because the F-stat value in Table 3 is more than 4 .

Table 3: Fixed Effect Analysis among construction sector firms

\begin{tabular}{|c|c|c|c|c|c|c|c|c|c|}
\hline & \multicolumn{3}{|c|}{ Independent Variables } & \multicolumn{2}{|c|}{ Control Variables } & \multirow{2}{*}{ F-stat } & \multirow{2}{*}{ Obs } \\
\hline & & & ITA & CAPEX & CCAPEX & SIZE & LVR & & \\
\hline \multirow{4}{*}{  } & \multirow[b]{2}{*}{$\underset{\approx}{\approx}$} & P-value & $\begin{array}{c}* \\
0.0774\end{array}$ & $\begin{array}{c}* * * \\
0.0011\end{array}$ & 0.1733 & $\begin{array}{c}* \\
0.0945\end{array}$ & $\begin{array}{c}\begin{array}{c}* * * * \\
0.0002\end{array} \\
\end{array}$ & \multirow{2}{*}{78.3464} & \multirow{4}{*}{518} \\
\hline & & Coeff & -0.0877 & 0.0000 & -0.0030 & -0.0112 & -0.1141 & & \\
\hline & \multirow[t]{2}{*}{$\stackrel{\text { ry }}{\approx}$} & P-value & 0.1594 & $\begin{array}{c}* * * * \\
0.0036\end{array}$ & $\begin{array}{c}* * * * \\
0.0051\end{array}$ & $\begin{array}{c}* \\
0.0758\end{array}$ & 0.4077 & \multirow[t]{2}{*}{8.0057} & \\
\hline & & Coeff & 0.1285 & 0.0002 & -0.2149 & -0.0467 & 0.0921 & & \\
\hline & & ignificant & vel at $1^{\circ}$ & Depender & ariables are & turn on a & (ROA) & d return & $\begin{array}{l}\text { equity } \\
\text { capital }\end{array}$ \\
\hline
\end{tabular}

\subsection{Pooled OLS Analysis across Different Economic Sub-Periods}

Table 4 shows the results of Pooled OLS analysis between capital investment and profitability across different economic subperiods. This analysis is done by using the proxy of the variables. In this study, there are three economic sub-periods including precrisis period (2001-2006), Global Financial Crisis period (2007$2009)$ and post-crisis period (2010-2014). From the data in table 4 , it is apparent that during pre-crisis period investment to asset is negatively related to return on asset while capital expenditure and current capital expenditure have positive relationship with return on asset. In return on equity, it shows a different scenario where only current capital expenditure has negatively relationship with return on equity.

Furthermore, during the global financial crisis period. What is interesting in the data is that current capital expenditure is positively significant to return on asset and return on equity at $1 \%$ and $5 \%$ level of significance. Other than that, during global financial crisis period it shows that investment to asset has negative relationship to return on asset. This indicates that investment to asset is not applicable during global financial crisis period. While for return on equity, it shows that capital expenditure has negative relationship to return on equity during Global Financial Crisis period. Moreover, investment to asset have positive significance relationship to return on equity at $5 \%$ level of significance.

In addition, the results highlighted that capital expenditure had a significant positive relationship with return on asset and return on equity at $5 \%$ level of significant during post-crisis period. Moreover, investment to asset and current capital expenditure were negatively related to return on asset in post-crisis period. However, investment to asset shows that it was positively related to return on equity during the same period. Besides that, the results also emphasized that current capital expenditure has significant positive relationship towards return on equity.
Table 4: Pooled OLS Analysis across different economic sub-periods

\begin{tabular}{|c|c|c|c|c|c|c|c|c|c|}
\hline & \multirow{2}{*}{\multicolumn{2}{|c|}{$\begin{array}{l}\text { Dependent } \\
\text { Variables }\end{array}$}} & \multicolumn{3}{|c|}{ Independent Variables } & \multicolumn{2}{|c|}{ Control Variables } & \multirow{4}{*}{$\begin{array}{l}\text { F-stat } \\
1.9337\end{array}$} & \multirow{4}{*}{\begin{tabular}{|l|}
$\mathrm{Obs}$ \\
222
\end{tabular}} \\
\hline & & & ITA & CAPEX & CCAPEX & SIZE & LVR & & \\
\hline \multirow{4}{*}{ 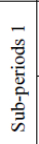 } & \multirow{2}{*}{$\underset{\varrho}{\approx}$} & P-value & 0.3723 & 0.1724 & 0.7578 & 0.6026 & 0.1713 & & \\
\hline & & Coeff & -0.0465 & 0.0001 & 0.0005 & 0.0021 & -0.1689 & & \\
\hline & \multirow{2}{*}{$\begin{array}{l}\text { In } \\
\approx\end{array}$} & P-value & 0.5404 & 0.1241 & 0.1690 & 0.7820 & 0.9460 & \multirow{2}{*}{19.9922} & \multirow{2}{*}{222} \\
\hline & & Coeff & 0.1364 & 0.0002 & -0.1963 & -0.0027 & 0.0105 & & \\
\hline \multirow{4}{*}{  } & \multirow{2}{*}{ @ } & P-value & 0.9859 & 0.8036 & $\begin{array}{c}* * * \\
0.0250\end{array}$ & 0.6895 & 0.1920 & \multirow{2}{*}{0.3274} & \multirow{2}{*}{111} \\
\hline & & Coeff & -0.0014 & 0.0002 & 0.0048 & 0.0314 & -0.1023 & & \\
\hline & \multirow{2}{*}{ 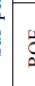 } & P-value & $\begin{array}{c}* * * \\
0.0378 \\
\end{array}$ & 0.6745 & 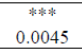 & 0.4167 & 0.3057 & \multirow{2}{*}{1.0421} & \multirow{2}{*}{111} \\
\hline & & Coeff & 0.3687 & -0.0003 & 0.1759 & 0.0863 & 0.0791 & & \\
\hline \multirow{4}{*}{ 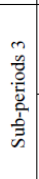 } & \multirow{2}{*}{ § } & P-value & 0.1747 & $\begin{array}{c}{ }^{* *} \\
0.0445 \\
\end{array}$ & 0.1186 & 0.3579 & $\begin{array}{c}w_{*}^{*} \\
0.0246\end{array}$ & \multirow{2}{*}{0.1011} & \multirow{2}{*}{185} \\
\hline & & Coeff & -0.0413 & 0.0007 & -0.0049 & 0.0113 & -0.1115 & & \\
\hline & \multirow{2}{*}{ 哭 } & P-value & 0.9485 & $\begin{array}{c}c^{* *} \\
0.0167 \\
\end{array}$ & $\begin{array}{c}* \\
0.0686 \\
\end{array}$ & 0.5346 & 0.6005 & \multirow{2}{*}{6.9782} & \multirow{2}{*}{185} \\
\hline & & Coeff & 0.0099 & 0.0003 & -0.2237 & -0.0391 & 0.1197 & & \\
\hline
\end{tabular}

**** denotes significant level at $1 \%$. Dependent variables are return on asset (ROA) and return on equity (ROE). Independent variables are investment to asset (ITA), capital expenditure (CAPEX) and current capital expenditure (CCAPEX). Control variables are size (SIZE) and Leverage (LVR). The sample periods are divided into three sub-periods, i.e., pre-crisis period from 2001 until 2006. Global Financial Crisis sub-periods from 2007 until 2009 and post-crisis period from 2010 until 2014

Furthermore, the coefficient shows that investment to asset and current capital expenditure have the largest effect towards return on asset except the Global Financial Crisis period. On the other hand, for return on equity. The result revealed that current capital expenditure has the largest impact but except for Global Financial Crisis period. In addition, there is changes in sub-period 1 and 2 where current capital expenditure had become positively related to return on asset which different from the overall analysis in previous section. Moreover, there are significantly changes of relationship in sub-period 2 compared to overall sample where capital expenditure and current capital expenditure shows different relationship with return on equity. This can be explained by the variables react differently during crisis period. This can be a good indicator and guidelines for the investor in construction sector.

Fixed Effect Analysis across Different Economic Sub-periods

Table 5 shows the results of the fixed effect analysis across different economic sub-periods. In this analysis, capital expenditure has significant positive relationship towards both return on asset and return on equity in pre-crisis period and post-crisis period at $1 \%$ level of significance and 5\% level of significance respectively. However, for Global Financial Crisis period, current capital expenditure has the significant relationship towards return on asset and return on equity at 5\% level of significance. As the crosssectional effect was fixed, during pre-crisis period, the results show that current capital expenditure has significant negative relationship towards return on equity at $1 \%$ level of significance.

On the other hand, for the period during Global Financial Crisis. The result highlighted that investment to asset has significant positive relationship towards return on equity at $1 \%$ level of significance but negative relationship towards return on asset. Other than that, the results indicated that current capital expenditure was the most important determinants during global financial crisis period that showing the result of significant positive relationship towards return on asset and significant negative relationship towards return on equity at $1 \%$ level of significance.

Besides that, for post-crisis period. All variables showing significant relationship towards return on asset and return on equity except investment to asset where it shows that it had insignificant relationship towards return on equity. In addition, investment to asset and current capital expenditure had significant negative relationship towards return on asset at $5 \%$ level of significance. However, capital expenditure shows that it positively related to return on asset at $5 \%$ level of significance. In this period, current capital expenditure was the most important and largest variable that affect both return on asset and return on equity.

Furthermore, the coefficient shows that investment to asset had the largest impact towards return on asset in every economic subperiod. While for return on equity, current capital expenditure still the largest impact determinants towards both return on asset and 
return on equity but during Global Financial Crisis period, investment to asset remained the most impactful variables towards return on asset and return on equity.

Other than that, the analysis of overall sample and analysis based on sub economic period have produce different results. For current capital expenditure, it changes from negative to positive relationship with return on asset during sub-period 1 and 2. For capital expenditure, it changes to negative relationship with return on equity during crisis period.

Table 5: Fixed Effect Analysis across different economic sub-periods

\begin{tabular}{|c|c|c|c|c|c|c|c|c|c|}
\hline & \multirow{2}{*}{\multicolumn{2}{|c|}{$\begin{array}{l}\text { Dependen: } \\
\text { Variables }\end{array}$}} & \multicolumn{3}{|c|}{ Independert Variables } & \multicolumn{2}{|c|}{ Control Variables } & \multirow{4}{*}{$\begin{array}{c}\text { F-tak } \\
218.0000\end{array}$} & \multirow{3}{*}{$\mathrm{Obs}$} \\
\hline & & & $\mathrm{Ira}$ & CAVEX & CCADEX & size & LVR & & \\
\hline \multirow{4}{*}{ d. } & \multirow{2}{*}{$\dddot{g}$} & Provalue & 0.1360 & 0.0005 & 0.4526 & 0.1776 & 0.0097 & & \\
\hline & & Coeff & 0.0488 & 0.0505 & 0.0007 & 0.0026 & .0 .1664 & & \\
\hline & \multirow[t]{2}{*}{8} & Prizalue & 0.3742 & $\begin{array}{c}+4 * \\
0.0001\end{array}$ & $\stackrel{+* 0}{0.003}$ & 0.4353 & 09592 & \multirow{2}{*}{194,7000} & \multirow{2}{*}{222} \\
\hline & & Cosff & 0.1580 & 0.0601 & -0.1082 & -0.0071 & -0.0114 & & \\
\hline \multirow{4}{*}{ है } & \multirow{2}{*}{$\S$} & Provalue & 0.8543 & 0.8256 & $\stackrel{* 0001}{0.000}$ & 0.6996 & 0.0632 & \multirow{2}{*}{65.0000} & \multirow{2}{*}{111} \\
\hline & & Cosff & -0.0124 & 0.0501 & 0.0049 & 0.0290 & -0.1003 & & \\
\hline & & Prizalue & $\begin{array}{c}\$ * 0001 \\
0.000\end{array}$ & 0.7947 & 0.0001 & 0.3509 & 0.1571 & \multirow{2}{*}{$\omega .1000$} & \multirow{2}{*}{111} \\
\hline & & Coeff & 0.3522 & -0.0002 & -0.1767 & 0.0797 & 0.0852 & & \\
\hline \multirow{4}{*}{ 光 } & \multirow{2}{*}{$\$$} & Provalue & 0.0342 & 0.0159 & $\begin{array}{c}41 \\
0.0432 \\
0\end{array}$ & 0.1875 & a.000s & \multirow{2}{*}{2.2696} & \multirow{2}{*}{186} \\
\hline & & Coeff & -0.0329 & 0.0009 & .0 .0058 & 0.0158 & 0.1107 & & \\
\hline & \multirow[t]{2}{*}{ है } & Provalue & 0.3929 & 0.0105 & 0.0681 & 0.6831 & 0.7208 & \multirow{2}{*}{1.4081} & \multirow{2}{*}{186} \\
\hline & & Coeff & 0.1494 & 0.0003 & .0 .22866 & .0 .0233 & 0.0732 & & \\
\hline \multicolumn{10}{|c|}{ 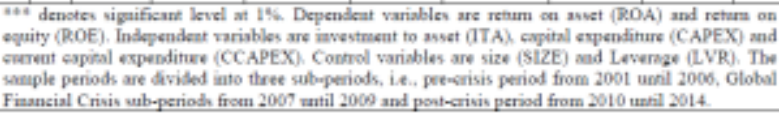 } \\
\hline
\end{tabular}

\section{Limitations of the Study}

In this study, the objectives of the study are achieved and discussed. However, there are still limitations which make this study not complete, which can be improved by future researchers. The sample size of this study is too small, as it focusses only on the construction firms in Malaysia. Hence, this topic should be extended other sectors. Lastly, the time frame can be adjusted to the period before 1997 which the result can become more specific and reliable.

\section{Future Research Recommendations}

This topic investigates the trend and effect of financial crisis on the profitability of the firms. The time frame of the study can be adjusted to longer period to the point whereby it can investigate the effect of financial crisis in 1998. Additionally, another sector in Malaysia could also be taken into consideration for detailed investigation of this study. For example, manufacturing sector and service sector could be the options, which are the two-major sector in Malaysia's economic. Other than that, future research can also focus on small and medium enterprises or private construction firms. Furthermore, Malaysia government implement Government Service Tax in 2015. This can also include in future research to investigate the effect of GST on profitability of construction firms.

\section{Conclusion}

This study was designed to have the insight about the relationship between capital investment and profitability of listed firms in construction sector of Malaysia. Based on the analysis that are done in the study, it shows that all the variables of profitability have significant impact and relationship towards return on asset and return on equity in different economic sub-periods. This study has shown that capital investment has clearly affects the profitability in different economic sub-period.

\section{References}

[1] Basu, D., \& Das, D. (2017). Profitability and Investment: Evidence from India's Organized Manufacturing Sector. Metroeconomica, 68(1), 47-90.

[2] Salawu, R. O. (2009). The effect of capital structure on profitability: an empirical analysis of listed firms in Nigeria. The International Journal of Business and Finance Research, 3(2), 121-129.

[3] Ramakrishnan, S., Mirzaei, M., \& Sanil, H. S. (2015). Corporate default prediction with data mining techniques. Indian Journal Of Research, 4(1), 161-165.

[4] Burja, C. (2011). FACTORS INFLUENCING THE COMPANIES'PROFITABILITY. Annales Universitatis Apulensis: Series Oeconomica, 13(2), 215.

[5] Ramakrishnan, S. (2012). Sectoral analysis on capital structure determinants among the Malaysia listed firms (No. Ph. D.). Deakin University.

[6] El Namaki, M. S. S. (2014). How damaged are investment capital markets today?. Competitiveness Review, 24(1), 51-58.

[7] Eklund, J. E. (2013). Theories of investment: a theoretical review with empirical applications. In Swedish Entrepreneurship Forum (p. 2).

[8] Ramakrishnan, S., Hishan, S. S., Shahabuddin, A. S. M., \& Kanjanapathy, M. (2016). The Role of Corporate Social Responsibility in Flood Mitigation among the Listed Insurance Companies in Malaysia. International Review of Management and Marketing, 6(4S).

[9] Raza, M. W. (2013). Affect of financial leverage on firm performance. Empirical evidence from Karachi Stock Exchange.

[10] Suto, M. (2003). Capital structure and investment behaviour of Malaysian firms in the 1990s: A study of corporate governance before the crisis. Corporate Governance: An International Review, 11(1), 25-39.

[11] Sheng, Y. H., \& Mykytyn Jr, P. P. (2002). Information Technology Investment and Firm Performance: A Perspective of Data Quality. In IQ (pp. 132-141).

[12] Javed, Z. H., Rao, H. H., Akram, B., \& Nazir, M. F. (2015). Effect of financial leverage on performance of the firms: Empirical evidence from Pakistan. SPOUDAI-Journal of Economics and Business, 65(1-2), 87-95.

[13]Zhu, Z., \& Huang, F. (2012). The effect of R\&D investment on firms' financial performance: Evidence from the Chinese listed IT firms. Modern Economy, 3(08), 915.

[14]Bentum, W. (2012). The Determinants of Profitability of the Commercial Banks in Ghana during the Recent Years of Global Financial Crisis. Retrieved July, 15, 2014.

[15]Hamidi, M. (2015). Determinants of Capital Expenditure Decisions in the Malaysian Companies. In Proceedings of the Australasian Conference on Business and Social Sciences 2015.

[16]Lööf, H., \& Heshmati, A. (2008). Investment and performance of firms: correlation or causality?. Corporate Ownership \& Control, 6(2), 268-282.

[17]Berger, A. N., \& Bouwman, C. H. (2009). Bank capital, survival, and performance around financial crises. Documento de trabajo, Wharton Financial Institutions Center. Disponible en: http://fic. wharton. upenn. edu/fic/papers/09/0924. pdf.

[18] Li, D. (2004). The implications of capital investment for future profitability and stock returns: an over-investment perspective(Doctoral dissertation, University of California, Berkeley).

[19]Lian, L. L., Ramakrishnan, S., Vaicondam, Y., \& Hishan, S. S. (2017). Capital Investment and Profitability Across Malaysian Consumer Products Sector. Advanced Science Letters, 23(9), 9282 9286.

[20] Mirzaei, A. (2013). Bank performance during the financial crisis 2007-2010. International Journal of Business and Economics, 12(1) 27.

[21] Sam, M., Fazli, M., \& Hoshino, Y. (2013). Sales Growth, Profitability and Performance: Empirical Study of Japanese ICT Industries with Three ASEAN Countries.

[22]Zaid, N. A. M., Ibrahim, W. M. F. W., \& Zulqernain, N. S. (2014, February). The Determinants of profitability: Evidence from Malaysian construction companies. In Proceedings of 5th Asia-Pacific Business Research Conference (pp. 17-18).

[23] Mukherjee, M., \& Pratap, K. V. (2011). The Impact of the Global Financial Crisis on Investments in the Electric Power Sector. The World Bank and ESMAP, Report, (56849-SAS).

[24]Castellan, C. M. (2010). Quantitative and qualitative research: A view for clarity. International journal of education, 2(2), 1. 
[25] Podestà, F. (2002). Recent developments in quantitative comparative methodology: The case of pooled time series cross-section analysis. DSS Papers Soc, 3(2), 5-44.

[26]Dang, C., Li, Z. F., \& Yang, C. (2018). Measuring firm size in empirical corporate finance. Journal of Banking \& Finance, 86, 159176. 